\title{
ABSORPTION OF LIPID BY THE SMALL INTESTINAL ENTEROCYTES OF THE CHICKEN
}

\author{
J. HOLMAN \\ Department of Pathological Morphology and Parasitology, Laboratory of Electron Microscopy, \\ University of Veterinary Science, 61242 Brno
}

Received fanuary 23, 1979

\begin{abstract}
Holman J.: Absorption of Lipid by the Small Intestinal Enterocytes of the Chicken. Acta vet. Brno, 48, 1979: 9-13.

Experiments were conducted to study the way of lipid absorption in the chicken small intestinal epithelium after peroral administration of sunflower oil. Chickens aged 14-to-23 days were used. The electron-microscopical examination showed that the lipids were absorbed by selective diffusion of monoglycerides and fatty acids by the entire free surface of enterocytes. Pinocytosis of non-hydrolyzed triglycerides was not observed. During lipid absorption in the apical portion of enterocytes there was no increased occurrence of pinocytotic invaginations or pinocytotic vesicles detectable.
\end{abstract}

Microvilli, plasma membrane, pinocytosis, monoglycerides, fatty acids,"chylomicrons.

The way of enteral absorption of lipids in mammals has been a matter of discussion since a long time. Hewitt (1953) admitted that a part of triglycerides is absorbed in the nonhydrolyzed form. Palay and Karlin (1959) after peroral administration of lipids to rats found well visible pinocytotic vesicles with lipid particles in the brush border of enterocytes just beneath the terminal web. Also Mohiuddin (1964) found the lipid droplets to be taken into the epithelial absorptive cells of the intestine by pinocytosis and to be given off by retropinocytosis.

The more recent studies based on introduction of ultrathin sections and elaborate biochemical methods have created the new lipolytic theory of lipid absorption. Lipids hydrolyzed in the intestinal lumen diffuse into the epithelial cells in form of glycerol and fatty acids. Within these cells their resynthesis occurs (Hofmann and Borgström 1962; Johnston and Borgström 1964; Senior 1964). This theory received much support by the morphological findings. Lipids were found to enter the epithelial cells through their microvilli in particularly small form approaching the size of molecules (Lacy and Taylor 1962). Lipid particles $50 \AA$ to $1000 \AA$ in size stained with $\mathrm{Pb}^{++}$were identified between, on or within the microvilli of the absorptive cells (Rostgaard and Barrnett 1965). These finding compared with micellar solutions stained in vitro indicated that lipids can be absorbed by diffusion in form of lipid particles according to the above-mentioned authors. Similarly, incubation of small intestinal segments in artificially prepared micellar solution showed that the lipids are absorbed by diffusion in form of particles of micellar or molecular size (Strauss 1966). According to Cardell et al. (1967) monoglycerides and fatty acids diffuse from micelles during their connection with microvillous membrane of the enterocyte. In rats, the enteral absorption of products of sunflower oil hydrolysis was studied by Dermer (1967). On the surface of fat-absorbing rat intestinal microvilli he found particles $100 \AA$ in size. Indentations between the microvilli and vesicles within the terminal web area, each surrounded by a membrane, did not contain globular material and they were observed in both experimental and control animals.

Sjöstrand and Bergström (1967) found after the fractionated centrifugation of homogenates from intestinal epithelial cells of the rat the labelled oleic acid and cholesterol in the smooth-surfaced vesicles of the apical part of enterocytes. These results support the view on resynthesis of triglycerides in the vesicles.

Zilversmit (1967) found the chylomicrons originating in the intestinal cells to consist of a network of triglyceride which is, according to its fatty acid composition, similar to the lipids derived from the food. 
The aim of the present work is to reveal the morphology of lipid absorption in the fowl. The way of entrance of lipids into the intestinal epithelial cell is important for the knowledge of the entire absorption, resynthesis and transport of lipids.

\section{Materials and Methods}

For the experiments sexed White Leghorn cockerels aged 14 to 23 days were used. They were fed a commercial mixture. Prior to the experiment, the birds were fasted for 24 hours with access to drinking water.

The cockerels were given $1 \mathrm{ml}$ sunflower oil into the crop by a thin tube. Groups of 3 chickens were killed at the intervals of 30,60 and 90 minutes after this treatment. The control group consisted of fasted birds.

From the killed birds, small pieces of jejunum near the Meckel's diverticulum were collected. The samples were fixed in veronal-acetate-buffered $1 \% \mathrm{OsO}_{4}(\mathrm{Palade} 1952)$ supplemented with saccharose (Caulfield 1957). After dehydration in graded concentrations of acetone the samples were embedded in Vestopal $W$.

Ultrathin sections were treated with uranyl acetate (Watson 1958) and lead citrate (Reynolds 1963) and examined with a Tesla BS 500 electron microscope.

\section{Results}

Ultrastructure of the apical portion of enterocyte in the fasted chickens

Jejunal absorptive cells are cylindrical with a striated border on their free surface. The striated border is formed by microvilli - finger-like projections covered with plasma membrane. Luminal surface of the plasma membrane is covered with a surface coat considered to consist of mucopolysaccharides. This layer is particularly well developed on the tips of microvilli. The stroma of microvilli is formed by fine, parallel filaments.

The area of terminal web is a thin zone below the microvilli containing no cellular organelles. In the terminal web abundant fine filaments parallel to the surface are present. The bundle of filaments forming the stroma of each microvillus joins on its basis the filaments of the terminal web. They further run together and cannot be distinguished from each other. At the basis of some microvilli pinocytotic invaginations occur. In the zone of terminal web and directly beneath it various amounts of apical vesicles (Fig. 1) can be seen. These originate from the apical pinocytotic invaginations of the plasma membrane and are of variable size and predominantly oval or round in shape. Their contents are usually transparent. They exceptionally contain electron-dense coarse material.

Smooth endoplasmic reticulum contains round or short tubular profiles (Fig. 2) which often branch and anastomose. They occur most frequently under the terminal web and are often accompanied by multivesicular bodies, lysosomes and free ribosomes.

Ultrastructure of the apical portion of enterocyte in chickens during fat absorption

Fine structure of the striated border during fat absorption does not differ from that found in fasted birds. No changes were found in the cytoplasmic membrane, filaments and optic density of microvilli.

Likewise, no changes were detected in the number and ultrastructure of pinocytotic invaginations and apical vesicles in the terminal web (Fig. 3). The contents of the vesicles were usually transparent. Filaments of the terminal web showed no changes as compared to the fasted birds. 
However, in the apical cytoplasm under the terminal web profound changes caused by lipid absorption were observed: in the vesicular profiles of the smooth endoplasmic reticulum and in the multivesicular bodies chylomicrons are present (Fig. 4). In the cytoplasm free lipid droplets larger than chylomicrons and with no surface membrane are visible. Their surface is intensely stained with lead citrate.

The system of smooth endoplasmic reticulum, scarcely developed in the fasted chickens, was observed to enlarge during fat absorption. Its profiles in the enterocyte cytoplasm are numerous. In cytoplasm under the terminal web predominantly cross-sections of smooth endoplasmic reticular profiles occur (Fig. 4). Lysosomes, sometimes present in the area of terminal web, contain chylomicrons only exceptionally.

\section{Discussion}

Ultrastructure of chicken small intestinal absorbing cells differs only slightly from that of mammals (Palay and Karlin 1959; Dunn 1967; Cardell et al. 1967). In chicken enterocytes less electron-dense surface coat on the surface of microvilli is present ( Hu m phrey and Turk 1974). Investigation of the fine structure of enterocyte microvilli in various segments of chicken intestine revealed differences in degree of development of the surface coat (Holman 1968). Its electron density is dependent on fixation and processing of the tissue.

Ingested lipids in the intestinal lumen do not directly contact the apical plasma membrane of absorptive cells but are separated from this membrane by the surface coat covering the microvilli. Ferlatte and Zeman (1977) presume that glycocalyx can operate during fat absorption. This presumption is based on the relation between the surface coat and lipid droplets. Except for the site of contact with the surface coat are the lipid droplets smooth and regularly oval. This suggests the participation of the surface coat in the enzymatic digestion of fats. However, in chickens no such phenomenon was observed.

In discussion on the question of enteral absorption of fats in mammals which was basically answered by the work of Cardell et al. (1967) two ways of lipid entrance into the absorptive cell were assumed, namely pinocytosis and passive diffusion of hydrolyzed fats. Pinocytosis was thought to be the main way of fat absorption (Palay and Karlin 1959; Mohiuddin 1964; Cornell and Padykula 1969). As the majority of authors was not able to detect any great extent of pinocytosis during fat absorption, at present the passive diffusion of hydrolyzed fats into the absorbing cells seems to be operative. This is based on the work of Hofmann and Borgström (1962) who observed the intestinal content to be composed of the oleic and micellar phase. Pancreatic lipase and bile salts decompose the triglycerides to micellar solution of monoglycerides and fatty acids which then both passively enter the cells through their plasma membrane (Strauss 1966; Cardell et al. 1967; Oledzka-Slotwinska and Desmet 1971; Ferlatte and Zeman 1977; Sabesin and Frase 1977). Our observations showed no increased occurrence of pinocytotic invaginations and vesicles in the apical part of enterocyte during the fat absorption in chickens. In the present study neither pinocytotic vesicles nor lipid droplets were demonstrated. These findings confirm the existence in birds of lipid absorption by passive diffusion through the entire free surface of enterocytes. 


\section{Resorpce tuku enterocytem tenkého střeva kuřete}

Po perorální aplikaci slunečnicového oleje 14 až 23 dní starým kuřatům byl elektronmikroskopicky sledován $\mathrm{v}$ tenkém střevě způsob vstřebávání tuku. Tuk je vstřebáván selektivní difusí monoglyceridů a mastných kyselin celým volným povrchem enterocytu. Pinocytosa nehydrolyzovaných triglyceridů nebyla pozorována. $\mathrm{V}$ průběhu vstřebávání tuku nedochází $\mathrm{v}$ apikální části enterocytů ke zvýšené frekvenci vzniku pinocytotických invaginací a pinocytotických váčků.

\section{Резорбция жира энтероцитом тонкой кишки цыпленка}

После пероральной подачи подсолнечного масла цыплятам в возрасте 14-23 дня проводились электронномикроскопические наблюдения способа всасывания жира в тонкой кишке. Жир впитывается селективной диффузией моноглицеридов и жирных кислот всей свободной поверхностью энтероцитов. Пиноцитоз негидролизованных триглицеридов не наблюдался. В ходе всасывания жира в апикальной части энтероцитов не происходит повышенная частота возникновения пиноцитотических инвагинаций и пиноцитотических мешочков.

\section{References}

CARDELL, R. R. Jr. - BADENHAUSEN, S. - PORTER, K. R.: Intestinal triglyceride absorption in the rat. An electron microscopical study. J. Cell. Biol., 34, 1967: 123-155.

CORNELL, R. - PADYKULA, H. A.: A cytological study of intestinal absorption in the suckling rat. Am. J. Anat., 125, 1969: 291-316.

DERMER, G. B.: Ultrastructural changes in the microvillous plasma membrane during lipid absorption and the form of absorbed lipid: An in vivo study. J. Ultrastruct. Res., 20, 1967: $51-71$.

DUNN, J. S.: The fine structure of the absorptive epithelial cells of the developing small intestine of the rat. J. Anat., 101, 1967: 57-69.

FERLATTE, M. I. - ZEMAN, F. J.: Lipid absorption in newborn rat intestine. Developmental Biology, 57, 1977: 1-14.

HEWITT, W.: The absorption of triolein from the small intestine of the rat. J. Anat., 87, 1953: 455.

HOFMANN, A. F. - BORGSTRÖM, B.: Physico-chemical state of lipids in intestinal content during their digestion and absorption. Fed. Proc., 21, 1962: 43-50.

HOLMAN, J.: Fine structure and dimensions of intestinal microvilli during the early postincubation period in chickens. Z. mikroskop.-anat. Forsch., 79, 1968: 14-26.

HUMPHREY, C. D. - TURK, D. E.: The ultrastructure of normal chick intestinal epithelium. Poultry Sci., 53, 1974: $990-1000$.

JOHNSTON, J. M. - BORGSTRÖM, B.: The intestinal absorption and metabolism of micellar solutions of lipids. Biochem, Biophys. Acta, 84, 1964: 412-423.

LACY, D. - TAYLOR A. B.: Fat absorption by epithelial cells of the small intestine of the rat. Am. J. Anat., 110, 1962: 155-185.

MOHIUDDIN, A.: The jejunal villi of the adult white rat during fat absorption. Acta anat., 59, 1964: $201-212$.

OLEDZKA-SLOTWINSKA, H. - DESMET, V. J.: Electron microscopic and cytochemical study on the role of Golgi elements and plasma membrane of enterocytes in the intestinal lipid transport. Histochemie, 28, 1971: 276-287.

PALADE, G. E.: A study of fixation for electron microscopy. J. Exp. Med., 95, 1952: 285-298.

PALAY, S. L. - KARLIN, L. J.: An electron microscopic study of the intestinal villus. II. The pathway of fat absorption. J. Biophys. Biochem. Cytol., 5, 1959: 373-384.

REYNOLDS, E. S.: The use of lead citrate at high $\mathrm{pH}$ as an electron-opaque stain in electron microscopy. J. Cell. Biol., 17, 1963: 208-212.

ROSTGAARD, J. - BARRNETT, R. J.: Fine structural observations of the absorption of lipid particles in the small intestine of the rat. Anat. Rec., 152, 1965: 325-350. 
SABESIN, S. M. - FRASE, S.: Electron microscopic studies of assembly, intracellular transport and secretion of chylomicrons by rat intestine. J. Lipid Res., 18, 1977: 496-511.

SENIOR, J. R.: Intestinal absorption of fats. J. Lipid Res., 5, 1964: 495-521.

SJÖSTRAND, F. S. - BORGSTRÖM, B.: The lipid components of the smooth-surfacedmembrane-bounded vesicles of the columnar cells of the rat intestinal epithelium during fat absorption. J. Ultrastruct., Res., 20, 1967: 140.

STRAUSS, E. W.: Electron microscopic study of intestinal fat absorption in vitro from mixed micelles containing linolenic acid, monoolein, and bile salt. J. Lipid Res., 7, 1966: 307-323.

WATSON, M. L.: Staining of tissue sections for electron microscopy with heavy metals. J. Biophys. Biochem. Cytol., 4, 1958: 475-478.

ZILVERSMIT, D. B.: Formation and transport of chylomicrons. Fed. Proc., 26, 1967: 1599-1605. 